\title{
Can Mode of Delivery cause Septal Deviation? A Retrospective Study
}

\author{
Mariam Al-Amro
}

\begin{abstract}
Objective: To establish whether septal deviation in infants with no previous trauma history is associated with the mode of their delivery.

Materials and methods: Records of patients treated for a deviated nasal septum from March 2003 to October 2014 were reviewed; those with previous facial trauma were excluded. Information retrieved included basic demographic data, mode of delivery, sibling birthing order, type and date of surgery, and postoperational outcomes.
\end{abstract}

Results: A total of 130 records were recovered. Comparison between normal delivery and cesarean section groups found no statistical significance (63 vs 67; p-value $>0.05$ ).

Conclusion: The mode of delivery, in uncomplicated cases, is not a cause of septal deviation.

Keywords: Cesarean section, Congenital septal deviation, Normal delivery.

How to cite this article: Al-Amro M. Can Mode of Delivery cause Septal Deviation? A Retrospective Study. Int J Otorhinolaryngol Clin 2018;10(1):11-12.

Source of support: Nil

Conflict of interest: None

\section{INTRODUCTION}

Having a deviated septum is usually the result of suffering mild to severe trauma to the face. However, in some cases, children present with a deviated nasal septum while never having suffered any such trauma. This has led doctors to put forth two possibilities: (1) that it is a structural anomaly that is genetically predetermined; or (2) that the mode in which the child was delivered is the causal factor.

Podoshin et $\mathrm{al}^{1}$ studied 4,090 neonates without evidence of trauma and they proposed that most of these dislocations had occurred during intrauterine life and the role of birth trauma as a factor is unclear.

Senior Registrar

Department of ENT, King Abdulaziz University Hospital, Riyadh Kingdom of Saudi Arabia

Corresponding Author: Mariam Al-Amro, Senior Registrar Department of ENT, King Abdulaziz University Hospital, Riyadh Kingdom of Saudi Arabia, Phone: +00966114786100, e-mail: dr.mariamalamro@hotmail.com
In one study by Kawalski and Spiewak, ${ }^{2} 273$ newborns were involved; anterior septal deviation was found in 49 of 221 (22\%) of those who were delivered spontaneously and in 2 of $52(3.8 \%)$ of those who were delivered via cesarean section. In another study, definite correlation between the type of delivery and nasal deformity was noted. ${ }^{3}$

In this study, we aim to study whether mode of delivery is indeed related to a high rate of septal deviation in those cases where there is no history of facial trauma.

\section{MATERIALS AND METHODS}

This retrospective study was approved by the Institutional Review Board of King Saud University, Riyadh, Kingdom of Saudi Arabia. Records for all patients attending the ear, nose, and throat clinic between March 2003 and October 2014 were reviewed, and those meeting the following criteria were included:

- Diagnosed with symptomatic septal deviation as a persistent obstruction.

- No previous history of facial trauma that is remembered by the parents/caregiver to cause such deviation.

From these records, patients' demographic data, mode of delivery, birth order (for siblings), corrective surgery procedure done, and condition on follow-up were noted down.

Statistical Package for the Social Sciences version 20 was used for all statistical analysis and the level of significance was set at $\mathrm{p} \leq 0.05$.

\section{RESULTS}

A total of 130 records met the inclusion criteria. Ages ranged from 6 to 18 years with mean of 15.1. Gender was mostly evenly distributed at 70 females to 60 males. Of these, 67 (51.5\%) were delivered normally and without instrumentation (forceps or ventouse), and 63 (48.5\%) were delivered via cesarean section. All babies were full term and deliveries were reported to be uneventful (Tables 1 to 3 ).

Statistical analysis on whether mode of delivery was related to having a deviated septum showed no significant correlation ( $\mathrm{p}$-value $>0.05$ ). The addition of other possible relevant variables, such as order of birth for siblings, had no discernable effect on the outcome. 


\begin{tabular}{|c|c|c|c|c|c|}
\hline \multicolumn{6}{|c|}{ Table 1: Gender } \\
\hline & & Frequency & Percent & $\begin{array}{l}\text { Valid } \\
\text { percent }\end{array}$ & $\begin{array}{l}\text { Cumulative } \\
\text { percent }\end{array}$ \\
\hline \multirow[t]{3}{*}{ Valid } & Male & 60 & 46.2 & 46.2 & 46.2 \\
\hline & Female & 70 & 53.8 & 53.8 & 100.0 \\
\hline & Total & 130 & 100.0 & 100.0 & \\
\hline
\end{tabular}

Table 3: Order of the child

\begin{tabular}{|c|c|c|c|c|c|c|}
\hline \multicolumn{3}{|c|}{$M O D$} & \multirow{2}{*}{$\begin{array}{l}\text { Frequency } \\
13\end{array}$} & \multirow{2}{*}{$\begin{array}{l}\text { Percent } \\
19.4\end{array}$} & \multirow{2}{*}{$\begin{array}{l}\begin{array}{l}\text { Valid } \\
\text { percent }\end{array} \\
19.4\end{array}$} & \multirow{2}{*}{$\begin{array}{l}\begin{array}{l}\text { Cumulative } \\
\text { percent }\end{array} \\
19.4\end{array}$} \\
\hline SVD & Valid & 1st child & & & & \\
\hline & & 2nd child & 14 & 20.9 & 20.9 & 40.3 \\
\hline & & 3rd child & 11 & 16.4 & 16.4 & 56.7 \\
\hline & & 4th child & 10 & 14.9 & 14.9 & 71.6 \\
\hline & & 5th child & 7 & 10.4 & 10.4 & 82.1 \\
\hline & & 6th child & 8 & 11.9 & 11.9 & 94.0 \\
\hline & & 7th child & 4 & 6.0 & 6.0 & 100.0 \\
\hline & & Total & 67 & 100.0 & 100.0 & \\
\hline \multirow[t]{8}{*}{ CS } & Valid & 1st child & 13 & 20.6 & 20.6 & 20.6 \\
\hline & & 2nd child & 11 & 17.5 & 17.5 & 38.1 \\
\hline & & 3rd child & 13 & 20.6 & 20.6 & 58.7 \\
\hline & & 4th child & 10 & 15.9 & 15.9 & 74.6 \\
\hline & & 5th child & 10 & 15.9 & 15.9 & 90.5 \\
\hline & & 6th child & 4 & 6.3 & 6.3 & 96.8 \\
\hline & & 7th child & 2 & 3.2 & 3.2 & 100.0 \\
\hline & & Total & 63 & 100.0 & 100.0 & \\
\hline
\end{tabular}

MOD: Mode of delivery

We found that mode of delivery in our study did not play a role in septal deviation, which is supported by $p$-value being $>0.05$ and it is not statistically significant. Also, we took into consideration if the child was the first child of the mother or not and what was the mode of delivery.

\section{DISCUSSION}

Incidence of deviated nasal septum in children varies in the literature between $2.9^{4}$ and 25\%. ${ }^{5}$ Many causes were mentioned in the literature to cause septal deviation in children, trauma being the chief among them. In cases where postpartum trauma is not in evidence, the appearance of septal deformities must come from other sources suggested, these being either congenital etiology or trauma, either during intrauterine life or during transit in the birth canal. ${ }^{6}$

Studies conducted by Reitzen et $\mathrm{al}^{7}$ support the noncongenital etiology for septum deviation, as they found that deviation occurs at a higher frequency in older
Table 2: Mode of delivery

\begin{tabular}{llllll}
\hline & & & & $\begin{array}{l}\text { Valid } \\
\text { percent }\end{array}$ & $\begin{array}{l}\text { Cumulative } \\
\text { percent }\end{array}$ \\
\hline \multirow{2}{*}{ Valid } & SVD & 67 & 51.5 & 51.5 & 51.5 \\
& CS & 63 & 48.5 & 48.5 & 100.0 \\
\hline & Total & 130 & 100.0 & 100.0 & \\
\hline
\end{tabular}

SVD: Spontaneous vertex delivery; CS: Cesarean section

children and adults than in younger children. However, they failed to take into account that the septum continues to grow throughout childhood, thus not being able to preclude the possibility of a genetic predisposition.

Concerning the possibility of a mode-associated correlation, Uygur et $\mathrm{al}^{8}$ concluded that there was a significant correlation between the mode of delivery and the incidence of septal deviation ( $p>0.05)$; other studies found the complete opposite. ${ }^{1}$ One of these studies was done by obstetricians in which they found that the frequency of nasal septal deformity was not higher in normal delivery compared with cesarean section. ${ }^{6}$

\section{CONCLUSION}

This study concludes that the mode of delivery in uncomplicated cases is not a cause of septal deviation and the incidence of septal deviation is the same for the first and subsequent babies.

\section{REFERENCES}

1. Podoshin L, Gertner R, Fradis M, Berger A. Incidence and treatment of deviation of nasal septum in newborns. Ear Nose Throat J 1991 Aug;70(8):485-487.

2. Kawalski H, Spiewak P. How septum deformities in newborns occur. Int J Pediatr Otorhinolaryngol 1998 Jun;44(1):23-30.

3. Bhattacharjee A, Uddin S, Purkaystha P. Deviated nasal septum in the newborn-a 1-year study. Indian J Otolaryngol Head Neck Surg 2005 Oct;57(4):304-308.

4. Kent SE, Reid AP, Nairn ER, Brain DJ. Neonatal septal deviations. J R Soc Med 1988 Mar;81(3):132-135.

5. Sooknundan M, Deka RC, Kacker SK, Verma IC. Nasal septal deviation at birth and its diagnosis. Indian J Paediatr 1986 Jan;53(1):105-108.

6. Korantzis A, Cardamakis E, Chelidonis E, Papamihalis T. Nasal septum deformity the newborn infant during labour. Eur J Obstet Gynecol Reprod Biol 1992 Mar;44(1):41-46.

7. Reitzen SD, Chung W, Shah AR. Nasal septal deviation in the pediatric and adult populations. Ear Nose Throat J 2011 Mar;90(3):112-115.

8. Uygur K, Yariktaş M, Tüz M, Döner F, Ozgan A. The incidence of septal deviation in newborns. Kulak Burun Bogaz Ihtis Derg 2002 Mar-Apr;9(2):117-120. 